\title{
Article \\ Efficient Amino Donor Recycling in Amination Reactions: Development of a New Alanine Dehydrogenase in Continuous Flow and Dialysis Membrane Reactors
}

\author{
David Roura Padrosa ${ }^{1,2}$, Zoya Nisar ${ }^{2}$ and Francesca Paradisi 1,2,*(D) \\ 1 Department of Chemistry and Biochemistry, University of Bern, Freiestrasse 3, 3012 Bern, Switzerland; \\ david.roura@dcb.unibe.ch \\ 2 School of Chemistry, University of Nottingham, University Park, Nottingham NG7 2RD, UK; \\ zoyanisar@outlook.com \\ * Correspondence: francesca.paradisi@dcb.unibe.ch; Tel.: +41-(0)-316-314-002
}

Citation: Roura Padrosa, D.; Nisar, Z.; Paradisi, F. Efficient Amino Donor Recycling in Amination Reactions: Development of a New Alanine Dehydrogenase in Continuous Flow and Dialysis Membrane Reactors. Catalysts 2021, 11, 520. https:// doi.org/10.3390/catal11040520

Academic Editor: Juan M. Bolivar

Received: 23 March 2021

Accepted: 15 April 2021

Published: 20 April 2021

Publisher's Note: MDPI stays neutral with regard to jurisdictional claims in published maps and institutional affiliations.

Copyright: (c) 2021 by the authors. Licensee MDPI, Basel, Switzerland. This article is an open access article distributed under the terms and conditions of the Creative Commons Attribution (CC BY) license (https:// creativecommons.org/licenses/by/ $4.0 /)$.

\begin{abstract}
Transaminases have arisen as one of the main biocatalysts for amine production but despite their many advantages, their stability is still a concern for widespread application. One of the reasons for their instability is the need to use an excess of the amino donor when trying to synthesise amines with unfavourable equilibria. To circumvent this, recycling systems for the amino donor, such as amino acid dehydrogenases or aldolases, have proved useful to push the equilibria while avoiding high amino donor concentrations. In this work, we report the use of a new alanine dehydrogenase from the halotolerant bacteria Halomonas elongata which exhibits excellent stability to different cosolvents, combined with the well characterised $\mathrm{CbFDH}$ as a recycling system of L-alanine for the amination of three model substrates with unfavourable equilibria. In a step forward, the amino donor recycling system has been co-immobilised and used in flow with success as well as re-used as a dialysis enclosed system for the amination of an aromatic aldehyde.
\end{abstract}

Keywords: enzyme immobilization; transaminase; amino acid dehydrogenase; flow biocatalysis

\section{Introduction}

Amines are one of the most important building blocks in the synthesis of pharmaceuticals, agrochemicals, and food additives. This ubiquity in commercial products, has led to an increased interest in creating more cost-efficient and "greener" strategies for their synthesis. In this sense, the use of enzymes as catalysts has provided significant advance in the sustainable synthesis of amines [1-4] and transaminases are primarily employed. Briefly, transaminases are a group of pyridoxal-5'-phosphate (PLP) dependant enzymes capable of transferring an amino group from an amino donor molecule (i.e., an amino acid) to an amino acceptor carbonyl group. This reaction is achieved through two half-reactions, where the amino group is first transferred into the PLP initially bound to the enzyme to form pyridoxamine- $5^{\prime}$-phosphate (PMP), which then reacts with the amino acceptor to form the final product and recover the coenzyme in its initial state, bound to the protein [5].

Although transaminases have already been implemented in the synthesis on large scale of important molecules such as Sitagliptin [6], aminotetraline, and acetophenone [7], their broad application is still hampered, specially, by their stability [8,9]. The loss of stability over time is attributable to the loss of the aminated cofactor after the first halfreaction is completed. This has two main plausible reasons: the binding affinity of the cofactor to the enzyme [10] and the presence of an excess of amino donor [11], commonly used to push the amination reaction for substrates with unfavourable equilibria.

To overcome the equilibrium limitation, several strategies have been proposed. The use of isopropyl amine (IPA) as the amino donor produces acetone, which can be easily removed by evaporation from the reaction bulk, forcing the reaction into the amination 
direction [12,13]. But IPA can significantly affect the stability of the enzyme [14], introducing a new challenge- - the presence of high amount of organics-into the reaction design. Similar problems arise when using S-methylbenzylamine (SMBA), o-xylylene diamine, or 2-(4-nitrophenyl)ethan-1-amine as the amino donors. Both shift the equilibria significantly, SMBA by producing a product which is not normally accepted by the transaminase for the reverse reaction and the other by effectively removing it from the system via polymerisation to create a black precipitate [15] or via tautomerisation to create a red precipitate [16]. These last two methods proved efficient for screening purposes but have not been exploited in synthesis. As an alternative, terminal diamines such as cadaverine (1,4-diaminopentane) or putrescine (1,4-diaminobutane) have also been used to push the equilibria. After deamination, in aqueous solutions, they cyclise forming an imine, pushing the equilibria [4]. With these type of molecules though, most tested $\omega$-transaminase exhibit low activities $[17,18]$. At last, another strategy is the use of multi-enzymatic systems, that even if more complex, can be advantageous due to their versatility. One of the most common strategies is the use of amino acid dehydrogenases for the recycling of frequent amino donors such as alanine [19-21]. Although they have promising results, amino acid dehydrogenases are cofactor dependant, which normally impacts the cost-effectiveness of the reaction. This can be solved by incorporating a recycling system for the cofactor [22,23]. Moreover, immobilisation of the enzymes allows their reuse, further increasing the cost-effectiveness of the reaction. In this sense, immobilisation of transaminases has been applied extensively to allow the process intensification [24-26]. In these examples though, no recycling system was applied to affect the equilibria and, when needed, an excess of amino donor was used to achieve satisfactory conversions. On the other hand, another approach for biocatalyst recycling consists in its confinement inside a membrane. In this case, instead of covalently immobilising the enzyme, which normally causes a loss of activity due to increased rigidification, the enzymatic cocktail is placed inside a dialysis membrane. This allows the free flow of the substrate and product in and out of the membrane but avoids the loss of enzyme to the reaction bulk, allowing its reuse in subsequent reactions, even in continuous using membrane reactors $[27,28]$.

In this work, the amination of substrates with unfavourable equilibria with two transaminases, CvTA (Chromobacterium violaceum transaminase) [29] and HeWT (Halomonas elongata $\omega$-transaminase) [30], was targeted. A new alanine dehydrogenase from the halotolerant bacteria H. elongata $(\mathrm{HeAlaDH})$ was cloned and characterised to be incorporated as a recycling system for alanine. The selection of $H$. elongata as a source for the AlaDH could in fact provide a highly compatible recycling system when this is coupled with HeWT. The new HeAlaDH was successfully coupled with both transaminases and NADH recycling system (formate dehydrogenase from Candida boidinii-CbFDH) [31] with three model substrates: cinnamaldehyde, vanillin, and cyclohexanone. To increase the reaction productivity and sustainability, two strategies were tested: the use of immobilised enzymes as packed bed reactors in continuous flow and as a soluble enzymatic cocktail enclosed in dialysis membranes.

\section{Results}

A gene coding for an alanine dehydrogenase (helo_3819) was identified in the genome of Halomonas elongata DSM 2581. This was cloned into a pRSETb vector, expressed in $E$. coli BL21(DE3) and purified by IMAC as a hexamer (confirmed by size exclusion chromatography). The new enzyme exhibited a high specificity for pyruvate as the main substrate, with very good resistance to organic solvents and basic $\mathrm{pH}$ (Figures S1-S4). $\mathrm{HeAlaDH}$ retained at least $50 \%$ of the activity with all tested cosolvents at $10 \%(v / v)$ and exhibited good resistance to $20 \%$ acetonitrile, methanol, and ethanol over $48 \mathrm{~h}$. As for the $\mathrm{pH}$, only acidic $(\mathrm{pH}<5)$ conditions seemed to have a negative effect on the enzyme stability. Overall, these characteristics make it a promising candidate for the coupling with transamination reactions. 


\subsection{Batch Amination of Unfavourable Carbonyl Acceptors}

To assess the suitability of HeAlaDH as an amino donor recycling system, coupled reactions with two different transaminases, CvTA and HeWT [30], were tested in batch with two aromatic aldehydes (cinnamyl aldehyde and vanillin) as well as a cyclic ketone (cyclohexanone). Previous results with equimolar SMBA as the amino donor yielded $\sim 30 \%$ cyclohexylamine and $45 \%$ vanillyl amine, whereas cinnamaldehyde conversion was better with a $60 \%$ conversion over $24 \mathrm{~h}$. The modest obtained conversions were explained by an unfavourable reaction equilibria [30], making them ideal substrates to test our system. Moreover, it is important to note that these substrates required at least 10\% dimethyl sulfoxide (DMSO) as co-solvent to be completely solubilised even at the $10 \mathrm{mM}$ scale, highlighting the importance of the co-solvent resistance required by the recycling system.

As no data was available in the literature for the conversion of these substrates with L-alanine as the amino donor, control reactions without any recycling system were also tested (Figure 1). Vanillin was assayed with 50, 5, and 1 eq. of L-alanine as amino donor (Figure S5). In the control, only $~ 50 \%$ of molar conversion was achieved over $24 \mathrm{~h}$ despite the use of concentrations of L-Ala up to $500 \mathrm{mM}$, with no significant conversion after $2 \mathrm{~h}$. On the other hand, when the reaction was coupled with HeAlaDH and $\mathrm{CbFDH}$, with just 1 eq. of the amino donor and 0.1 eq. of the cofactor, HeWT was able to aminate all vanillin at the $10 \mathrm{mM}$ in only $2 \mathrm{~h}$ (Figure 1). For cinnamyl aldehyde, the reaction could be enhanced even further. With 1 eq. of L-alanine, HeWT alone was only able to convert $10 \%$ of the substrate while in the presence of the recycling system it reached completion within $2 \mathrm{~h}$. The same conversion could be obtained even when reducing the L-Ala to just $0.1 \mathrm{eq}$. The cyclohexanone/L-Ala pair was significantly worse than the cyclohexanone/SMBA, yielding only $5 \%$ of the product in the control system even with 10 eq. of the amino donor. However, the addition of the recycling system pushed the reaction to complete conversion in $24 \mathrm{~h}$. When 1 eq. of amino donor was tried with the recycling system, the conversion was still significant, reaching $>80 \%$ after one day.

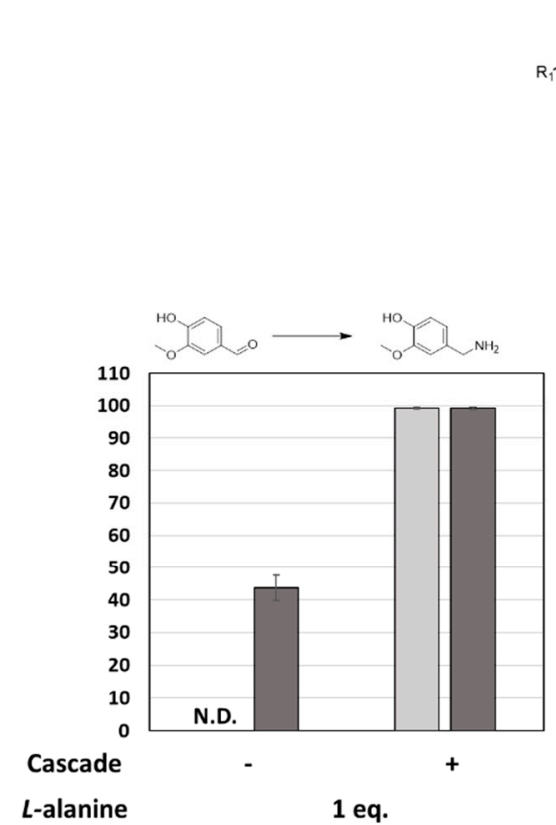

(a)
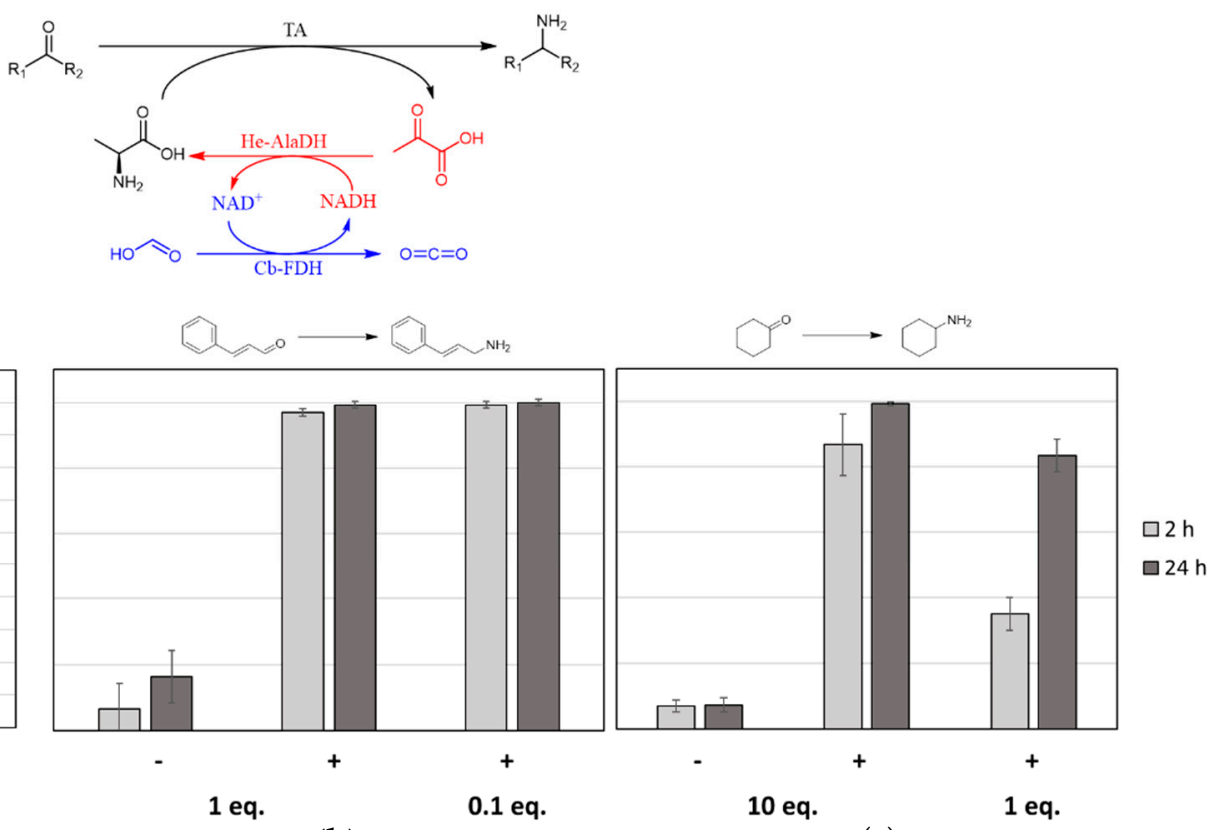

(b)

(c)

Figure 1. Conversions are expressed as \% of molar conversion. The reaction performed with HeWT alone is indicated with a "- " while the presence of the recycling system $(\mathrm{HeAlaDH}$ and $\mathrm{CbFDH})$ is indicated with a " + ". Reactions contained $2 \mathrm{mg} / \mathrm{mL}$ of HeWT, $0.5 \mathrm{mg} / \mathrm{mL}$ of HeAlaDH, $1 \mathrm{mg} / \mathrm{mL}$ of $\mathrm{CbFDH}$ with $10 \mathrm{mM}$ of the corresponding aldehyde or ketone, $1 \mathrm{mM} \mathrm{NAD}^{+}, 100 \mathrm{mM}$ of ammonium formate, and the desired concentration of alanine in $100 \mathrm{mM}$ phosphate buffer pH 8 . N.D. refers to not detected. (a) Vanillin $(10 \mathrm{mM})$ conversion in batch with different amounts of alanine. (b) Cinnamaldehyde amination with equimolar and sub-stoichiometric amount of the L-alanine as the amino donor. (c) Amination of $10 \mathrm{mM}$ cyclohexanone with 10 equivalents or 1 equivalent of L-alanine. 
To better understand the contribution of each of the components in the cascade, the reaction rate of these biotransformations was further studied, with both HeWT and CvTA and vanillin as the amino acceptor. The effect of the substrate concentration (at 10 and $50 \mathrm{mM}$ ) was examined (Figure 2 and Figure S6). Interestingly, the results indicate that the contribution of HeAlaDH alone is negligible when using the equimolar amount of alanine and cofactor. Only when the whole system was assembled, thus maintaining the pool of reduced cofactor, significant increase in the reaction rate were achieved. As for the effect of the substrate concentration, the reaction rate increased in both cases at the higher scale. This fact could be attributed to an increased capacity of HeAlaDH for pyruvate recycling into alanine and for the transaminase to accept the amino donor. Despite the increased reaction rate, at the higher scale, the maximum molar conversion of the substrate was reached after $72 \mathrm{~h}$ ( $70 \%$ for HeWT and $86 \%$ for CvTA). In addition, using 0.2 eq. of alanine with $50 \mathrm{mM}$ of the aldehyde substrate, slightly decreased the reaction rate. This suggests a higher dependency of HeWT to the alanine concentration, as the reaction rate was similar to the one at $10 \mathrm{mM}$ scale. In contrast, for CvTA, the reaction rate was only slightly decreased $(0.83 \pm 0.13$ compared to $1.36 \pm 0.39 \mathrm{mmols} / \mathrm{min})$.

(a)

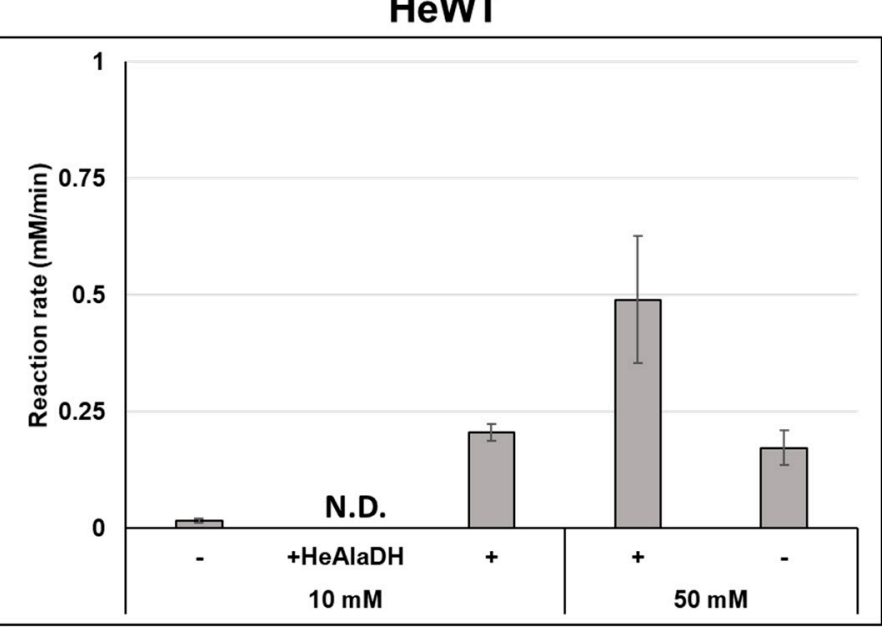

(b)

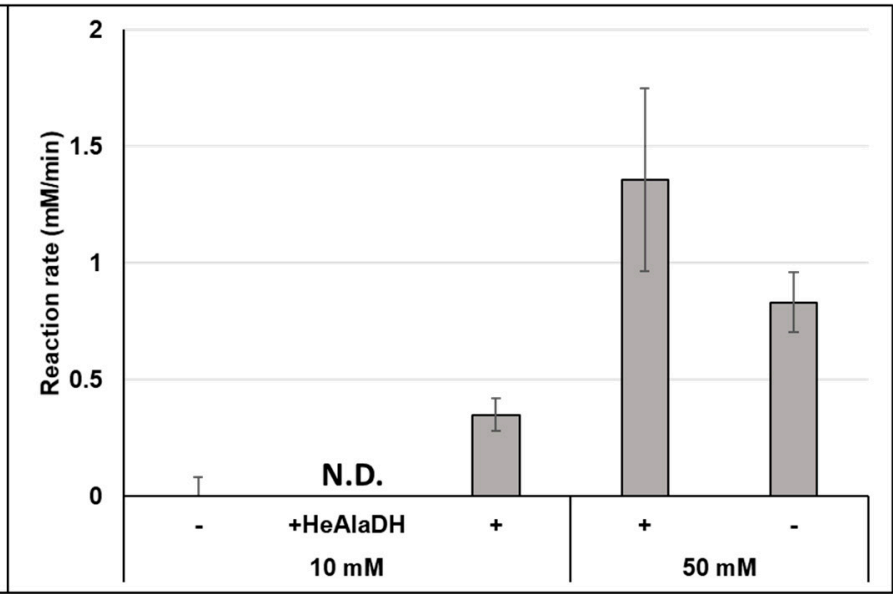

Figure 2. Reaction rate for the amination of vanillin. In the graphs on the left (a), the comparison between the transaminase alone $(-)$, combined with the alanine dehydrogenase $(+\mathrm{HeAlaDH})$ or the whole assembled system $(+)$ are reported. On the right (b), the comparison of the reaction rate at 10 and $50 \mathrm{mM}$ scale with different equivalents of the amino donor is depicted. Reactions were monitored for the first two hours. The reaction rate was estimated on the linear range. Reactions were performed with $2 \mathrm{mg} / \mathrm{mL}$ of TA, $1 \mathrm{mg} / \mathrm{mL}$ of HeAlaDH, $1 \mathrm{mg} / \mathrm{mL} \mathrm{CbFDH}$ with 10 or $50 \mathrm{mM}$ of vanillin, 10 or $50 \mathrm{mM}$ of L-alanine, $100 \mathrm{mM}$ ammonium formate, 0.1 eq. of $\mathrm{NAD}^{+}$in $100 \mathrm{mM}$ phosphate buffer $\mathrm{pH} 8$ with $10 \%$ DMSO. N.D. refers to not detected.

\subsection{Enzyme Immobilisation}

Once the system was characterised in a homogenous system, to increase the sustainability and specially, the reusability of the biocatalysts involved, immobilisation onto a solid support was tested. As HeWT, CvTA, and CbFDH had been previously immobilised $[25,32,33]$, the attention was brought to HeAlaDH. Taking advantage of the presence of the His-tag in $\mathrm{HeAlaDH}$, a previously described directed epoxy based covalent immobilisation technique was used [34].

Fixing the amount of immobilised enzyme to $0.5 \mathrm{mg} / \mathrm{g}$, different supports for the covalent immobilisation of HeAlaDH in epoxide groups was attempted (Table S1). From the methacrylic supports, HFA403-S allowed up to a $32 \pm 2 \%$ of recovered activity and epoxy agarose, with similar pore size and higher hydrophilicity, increasing the recovered activity to up to $42 \pm 1 \%$. Despite the good recovered activities, the stability of the catalyst was poor, loosing up to $50 \%$ when reusing it 5 times. This is an unusual behaviour as many 
immobilised enzymes acquire a much higher operational stability, however HeAlaDH is a hexamer and upon boiling the resin, it became obvious that not all the subunits where covalently immobilised (Figure S7). For multimeric enzymes, the loss of subunits has been seen before as one of the causes of poor reusability. To prevent this, several post-immobilisation coating techniques have proven to be effective [35-37]. In the case of HeAlaDH, glutaraldehyde (GA) seemed to have a negative effect, with almost a $15 \%$ decrease in the recovered activity, probably due to the capacity of this small molecule to permeate in the protein and potentially over-rigidifying the enzyme or even affecting the active site. On the other hand, bigger polymers such as polyethyleneimine (PEI) and dextran aldehyde seemed to have no impact on the recovered activity but allowed the creation of a biocatalyst with stable activity for at least 10 cycles.

Once the immobilisation of HeAlaDH was optimised, the creation of a redox-neutral recycling system was tested by co-immobilising $\mathrm{CbFDH}$ since both enzymes seemed to be necessary to increase the amination rate and co-immobilisation can enhance enzyme cooperativity [38]. In this case, HFA403-S, EC/HFA403-S, and Ep-Ag were selected due to their compatibility with both enzymes and the immobilisation was tested with sequential or simultaneous addition of the enzymes, followed by a PEI coating (Table S3).

Surprisingly, despite the lower recovered activities for $\mathrm{CbFDH}$, the resin where the two enzymes where co-immobilised simultaneously outperformed the other preparations when tested in combination with soluble CvTA in the amination of vanillin (Figure 3). As seen before with the soluble enzyme, maintaining NADH available for the alanine dehydrogenase seems to be key to push the amination reaction.

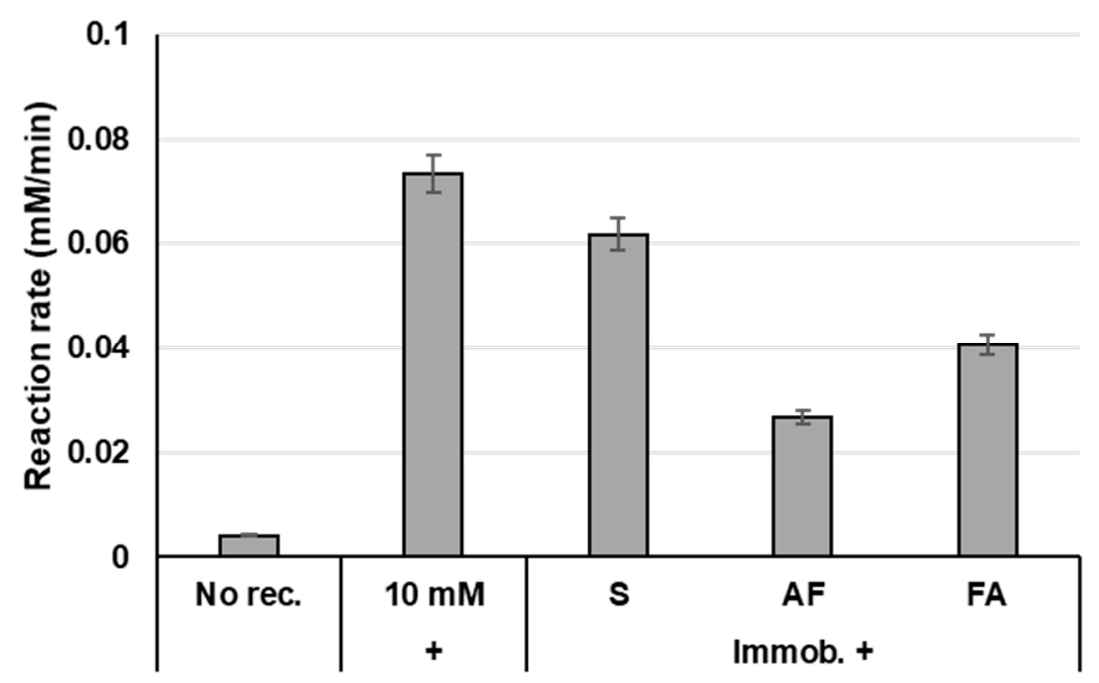

Figure 3. Reaction rate for the amination of vanillin. In all cases, the reaction consisted of $10 \mathrm{mM}$ vanillin, 1 eq. of alanine, $250 \mathrm{mM}$ ammonium formate, $1 \mathrm{mM} \mathrm{NAD+,} 0.1 \mathrm{mM}$ PLP with $2 \mathrm{mg} / \mathrm{mL}$ of CvTA and $20 \mathrm{mg}$ of the immobilised biocatalyst (S: simultaneous immobilisation; AF: HeAlaDH followed by $\mathrm{CbFDH}$ and FA: CbFDH followed by HeAlaDH).

In conclusion, for the creation of a self-sufficient biocatalyst, the best performing preparation was the simultaneous immobilisation of HeAlaDH and CbFDH $(1 \mathrm{mg} / \mathrm{g}$ support and $5 \mathrm{mg} / \mathrm{g}$ of support, respectively) with post-immobilisation coating with PEI to avoid HeAlaDH subunit loss during operation.

\subsection{Scale Up: Continuous Flow and Reusability in Batch}

In a step forward, the process intensification was attempted using the immobilised enzymes in a packed bed reactor using vanillin as substrate (Table 1). For the continuous flow, HeWT rather than CvTA was used due to its higher stability in flow $[25,32]$. In this case, $1 \mathrm{~g}$ of transaminase (the recovered activities are indicated in Table S4) was mixed with $2 \mathrm{~g}$ of co-immobilised HeAlaDH and $\mathrm{CbFDH}$. With the methacrylic resins, although the 
conversion reached up to $50 \%$, the product remained trapped in the column. Conversion could be assessed by the remaining vanillin once the column was saturated. All efforts to solve this issue were unsuccessful, either because the use of a segmented flow with the addition of an immiscible organic solvent inactivated the cofactor recycling system, or because the final yield was worsened when increasing the ionic strength in the buffer, or with the addition of surfactants. In another attempt, the more hydrophilic resin (Ep-Ag) was tested to circumvent high substrate/product affinity for the support. In this case, recovery of the product was possible and while the transaminase alone only achieved $23 \%$ conversion independently of the retention time, the conversion doubled with the full system at longer retention time.

Table 1. Molar conversion of vanillin using a packed bed reactor. Pump A reservoir contained $20 \mathrm{mM}$ vanillin in phosphate buffer pH8 with 20\% ( $v / v)$ DMSO. Pump B reservoir contained $20 \mathrm{mM}$ L-alanine, $200 \mathrm{mM}$ ammonium formate, $2 \mathrm{mM} \mathrm{NAD}^{+}$and $50 \mathrm{mM}$ phosphate buffer $\mathrm{pH} 8$. The reaction consisted of $10 \mathrm{mM}$ vanillin, $10 \mathrm{mM}$ L-alanine, $100 \mathrm{mM}$ ammonium formate, $1 \mathrm{mM} \mathrm{NAD}^{+}$in $50 \mathrm{mM}$ phosphate buffer $\mathrm{pH} 8$ with $10 \%$ DMSO. Conversions were assessed by HPLC.

\begin{tabular}{|c|c|c|c|}
\hline & co-in & AlaDH + & \\
\hline Support & Retention Time & TA & $\mathrm{TA}+\operatorname{Rec}$ \\
\hline \multirow{2}{*}{ HFA403-S } & $10 \mathrm{~min}$ & $<5 \%$ & $22 \pm 2$ \\
\hline & $20 \mathrm{~min}$ & $<5 \%$ & $50 \pm 12$ \\
\hline \multirow{2}{*}{ Ag-Ep } & $10 \mathrm{~min}$ & $22 \pm 5$ & $29 \pm 5$ \\
\hline & $20 \mathrm{~min}$ & $23 \pm 5$ & $40 \pm 5$ \\
\hline
\end{tabular}

Despite the improved results, these were far from what could be obtained in the batch reaction where in $2 \mathrm{~h}$ full conversion of both vanillin and cinnamaldehyde was achieved. Taking advantage of the better performance of the enzymes in their soluble form and to prevent the inactivation of $\mathrm{HeFDH}$ after immobilisation, another strategy was adopted. Very recently, it has been reported that the enclosure of a laccase in a dialysis bag retains the original activity of the enzyme and help its reusability, avoiding protein immobilisation [39].

To test the dialysis membrane enclosed system, the enzyme cocktail $(1 \mathrm{mg} / \mathrm{mL}$ CvTA, $1 \mathrm{mg} / \mathrm{mL} \mathrm{HeAlaDH}$, and $2 \mathrm{mg} / \mathrm{mL} \mathrm{CbFDH}$ ) was placed inside a dialysis bag which was then put inside a reaction vessel containing up to 5 times the volume of the enzymatic mix. In this case, the reaction achieved completion over $24 \mathrm{~h}$ (Figure $4 \mathrm{a}$ ) and, the enzymatic mix could be reused to some extent (Figure $4 \mathrm{~b}$ ) with both aromatic substrates, although conversion dropped to almost half for cinnamaldehyde already in the second cycle.

To overcome this low reusability, especially with cinnamaldehyde, the stabilising effect of different water-soluble polymers and small molecules was investigated. Previous studies found that polyols, such as polyethylene glycol (PEG) or small alcohols (glycerol and sugar moieties), can be used in the stabilisation of different biocatalysts [40]. On the other hand, polyamines such as polyethyleneimine (PEI) have also been related to increased stability of some proteins [41]. Based on these, 5 different molecules were tested: PEI, PEG, glycerol, and sucralose (Table 2). 


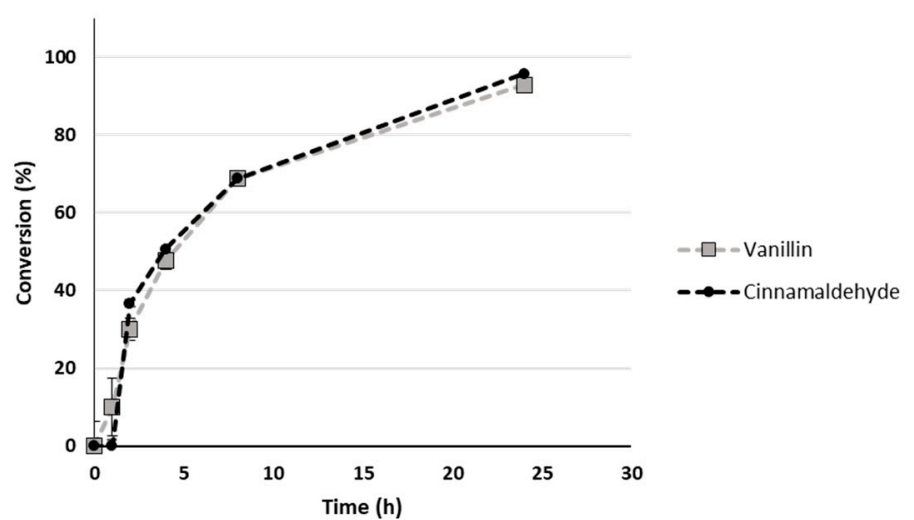

(a)

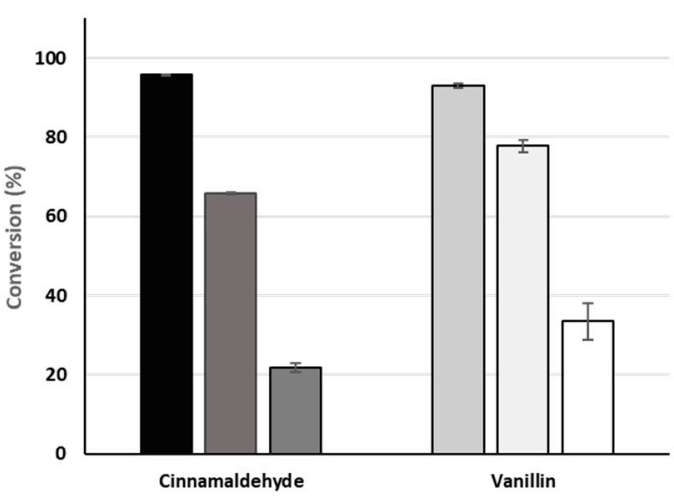

(b)

Figure 4. Conversion of cinnamaldehyde and vanillin to their corresponding amines in the dialysis system. (a) Conversion over time for the first cycle. (b) The reusability of the system is shown. The reaction mixture contained $10 \mathrm{mM}$ of the corresponding aldehyde, $10 \mathrm{mM}$ L-alanine, $250 \mathrm{mM}$ ammonium formate, $1 \mathrm{mM}$ NAD+, $1 \mathrm{mM}$ PLP and the enzymatic cocktail contained $1 \mathrm{mg} / \mathrm{mL}$ of CvTA, $1 \mathrm{mg} / \mathrm{mL}$ of $\mathrm{HeAlaDH}$, and $2 \mathrm{mg} / \mathrm{mL}$ of CbFDH.

Table 2. Effect of different stabilising agents on the overall yield after 3 cycles of the dialysis assisted scale up. Reactions consisted of $4 \mathrm{~mL}$ of $10 \mathrm{mM}$ cinnamaldehyde, 1 eq. of $L$-alanine, $250 \mathrm{mM}$ ammonium formate, $1 \mathrm{mM} \mathrm{NAD}^{+}, 0.1 \mathrm{mM}$ PLP in $100 \mathrm{mM}$ phosphate buffer $\mathrm{pH}$. The enzymatic mix was $1 \mathrm{mg} / \mathrm{mL}$ of CvTA, $1 \mathrm{mg} / \mathrm{mL}$ of $\mathrm{HeAlaDH}$, and $2 \mathrm{mg} / \mathrm{mL}$ of $\mathrm{HeFDH}$ in phosphate buffer $\mathrm{pH} 8$ and a total volume of $0.5 \mathrm{~mL}$. Each cycle was run for $24 \mathrm{~h}$.

\begin{tabular}{|c|c|c|c|}
\hline Additive & $\begin{array}{l}\text { Concentration } \\
(\mathrm{mg} / \mathrm{mL})\end{array}$ & Accumulated Yield (\%) & Relative Improvement \\
\hline Control & - & 52 & 1 \\
\hline PEI25 & \multirow{4}{*}{2.5} & 53 & 1 \\
\hline PEI60 & & 48 & 0.9 \\
\hline PEI270 & & 61 & 1.2 \\
\hline PEI750 & & 51 & 1.0 \\
\hline \multirow{3}{*}{ PEG } & 25 & 51 & 1.0 \\
\hline & 50 & 65 & 1.3 \\
\hline & 100 & 57 & 1.1 \\
\hline \multirow{3}{*}{ Glycerol } & 100 & 54 & 1.1 \\
\hline & 150 & 70 & 1.4 \\
\hline & 200 & 72 & 1.4 \\
\hline \multirow{3}{*}{ Sucralose } & 10 & 55 & 1.1 \\
\hline & 50 & 69 & 1.3 \\
\hline & 100 & 57 & 1.1 \\
\hline
\end{tabular}

From the different range of concentrations and additives tested, $50 \mathrm{mg} / \mathrm{mL}$ PEG, $15 \mathrm{mg} / \mathrm{mL}$ and $20 \%$ glycerol, and $50 \mathrm{mg} / \mathrm{mL}$ sucralose seemed to improve the reaction up to 1.4 times compared to the control, achieving around $70 \%$ accumulated conversion over the 3 cycles. These conditions were shown to stabilise the enzymes, at least for $24 \mathrm{~h}$, with either no effect or increased activity after $24 \mathrm{~h}$ for all three enzymes. In the case of PEI, no real improvement could be seen in any of the cases, probably due to decreased stability of the transaminase and the formate dehydrogenase in those conditions. Interestingly though, HeAlaDH was hyperactivated in those conditions with almost 3 times more activity after $24 \mathrm{~h}$ with PEI of $60 \mathrm{KDa}$ and higher mass (Figure S8). 


\section{Discussion}

The production of amines, as building blocks for many nutraceutical molecules, is a major focus not only in research but also at the industrial level. Thus, the application of biocatalytic strategies to circumvent their instability in high concentration of amino donor is of special interest to access amines with unfavourable equilibria. Here, HeAlaDH proved to be a versatile enzyme due to its high resistance to organic solvents and different $\mathrm{pH}$ range to be applied in combination of a transaminase to push the equilibria further. In addition, here we observed that not only L-alanine recycling enhances the final yield, but the recycling of the cofactor is of key importance to avoid the competition between the transaminase and the alanine dehydrogenase for L-alanine as the substrate. Thus, in our case, the combination with a cofactor recycling enzyme is key to affect the transamination equilibria. This strategy has been used in two intensification processes: continuous flow and as dialysis enclosed biocatalyst. In the first approach however, the use of $\mathrm{CbFDH}$ as the cofactor recycling enzyme in its immobilized form lead to poorer performance, confirming previous reports which indicated its sensitivity to covalent immobilisation [33]. Although the remaining activity yielded decent conversion in our case, it poses a problem for its wider application as a cofactor recycling system. Other enzymes, such as glucose dehydrogenases [28], could be used for the recycling of the cofactor but complexity of the system is increased with the added substrate and product generated. To surpass this limitation, the use of other formate dehydrogenases, which pose the advantage of limited residues and excellent atom economy, capable to better withstand covalent immobilisation could greatly benefit the proposed system. On the other hand, when using methacrylate resins as support, their hydrophilicity had major effect on the product recovery, but the presence of the cascade allowed 2-fold higher concentrations in the same retention time. Nonetheless, the use of agarose as the support for immobilisation allowed continuous recovery of both product and substrate (with no retention on the column) with $40 \%$ conversions in 20 min retention time. Compared to the methacrylic resin, with almost the same conversion, the direct recovery of the product without any entrapment in the matrix poses a major advantage.

In the second approach, while the conversions matched with the ones with the free enzyme in the first cycle, subsequent reactions showed decreasing conversions which related to poor stability of the biocatalyst for long reaction times. To enhance their stability, medium engineering through the addition of stabilising agents was attempted. Following previous reports, polyethyleneimines and alcohol containing molecules were chosen for the tests [40-42]. While most of these additives are common in protein storage buffers (specially glycerol), we wanted to investigate if their effect would also translate in higher operational stability. It is also important to note that the use of polymers with high molecular weight (such as PEI or PEG) inside the dialysis membrane, which has a higher molecular weight cut off (MWCO), also prevents their leak to the reaction bulk. In the best conditions, a final yield of over $70 \%$ after 3 cycles could be obtained with glycerol at concentrations of at least $150 \mathrm{mg} / \mathrm{mL}$, followed by PEG and sucralose at $50 \mathrm{mg} / \mathrm{mL}$ which also had a beneficial effect. These results, in combination with the stability assays performed with the same additives, clearly indicate that for this enzymatic cocktail, alcohol containing molecules are the best choice as they have a beneficial effect for all the enzymes involved. PEI on the other hand, has a positive effect for HeAlaDH but results in reduced stability for both the transaminase and the $\mathrm{CbFDH}$. These results indicate that the choice of stabilising agents highly depends on the enzymatic system used. It is important to note here, that while the substrate concentration is the same as in the free enzyme biotransformations in each reaction, bigger reaction volumes can be used without scaling up the amount of enzyme, which multiplies the total turnover number of the enzyme.

\section{Materials and Methods}

\subsection{Materials, Strains, Vectors, and Culture Conditions}

All chemical reagents, unless stated otherwise, were purchased as analytical grade from Sigma-Aldrich, Gillingham, U.K., Acros Organics or Thermo Fischer Scientific, Lough- 
borough, U.K. NAD ${ }^{+}$was purchased from Apollo Scientific Ltd., Stockport, U.K. Sepabeads and Relyzime supports for enzyme immobilisation were kindly provided by Residindion S.L. Agarose 6 BCL was purchased from Agarose Bead Technologies (ABT), Madrid, Spain.

\subsection{Protein Expression and Purification}

For HeWT and CvTA, one single colony was inoculated directly in the flask with either 50 or $300 \mathrm{~mL}$ of ZYP-5052 media supplemented with the ampicillin $(100 \mu \mathrm{g} / \mathrm{mL})$ and allowed to grow for $20 \mathrm{~h}$ at $37^{\circ} \mathrm{C}$. For the other two proteins (HeAlaDH and $\mathrm{CbFDH}$ ), an overnight pre-inoculum of at least $10 \mathrm{~mL}$ was prepared the day before and 1/100 of the final volume added to either 50 or $300 \mathrm{~mL}$. HeAlaDH was expressed in Terrific Broth media supplemented with ampicillin $(100 \mu \mathrm{g} / \mathrm{mL})$ and $\mathrm{CbFDH}$ in LB media supplemented with kanamycin $(30 \mu \mathrm{g} / \mathrm{mL})$. When the OD600 of these last two reached $0.6-0.8$, protein expression was induced with the addition of $1 \mathrm{mM}$ IPTG and the cultures were allowed to grow for $20 \mathrm{~h}$ at $30^{\circ} \mathrm{C}$. After that, cell cultures were harvested at $4000 \mathrm{rpm}$ for $20 \mathrm{~min}$ at $4{ }^{\circ} \mathrm{C}$ in the appropriate centrifuge tubes and the cells separated from the medium. The supernatant was carefully removed, and the cells resuspended in a minimum of $2 \mathrm{~mL}$ of loading buffer/g of pellet. The cell lysis was performed in ice using the sonicator in pulse mode ( $5 \mathrm{~s}$ on, $10 \mathrm{~s}$ off) for a minimum of $5 \mathrm{~min}$. The lysate was then centrifuged at $14,500 \mathrm{rpm}$, for a minimum of $45 \mathrm{~min}$ at $4{ }^{\circ} \mathrm{C}$. The collected supernatant was filtered with $0.45 \mu \mathrm{m}$ Millex PVDF filters before loading onto the Ni2+ preloaded columns. The affinity chromatography was performed using an AKTA Start system with the appropriate column. The filtered crude extract was loaded and left washing until the non-specific proteins were completely eluted. After that, an isocratic wash step with only $5-10 \%$ of elution buffer was performed to elute the non-specific proteins still bound onto the column. Finally, $100 \%$ of elution buffer was passed through the column and protein elution monitored by UV. Fractions were collected and those containing the desired protein pooled and placed into dialysis tubing. The protein samples were dialysed at least for $20 \mathrm{~h}$ replacing the buffer at least 2 times at $4{ }^{\circ} \mathrm{C}$. All proteins were dialysed against $50 \mathrm{mM}$ phosphate buffer $\mathrm{pH} 8$ and $0.1 \mathrm{mM}$ of PLP was added for HeWT. The pure proteins were stored at $4{ }^{\circ} \mathrm{C}$. Protein quantification was performed using a Take3 plate in an EPOCH2 by measuring the absorbance at $280 \mathrm{~nm}$. The molar extinction coefficient and molecular mass are: $24,500 \mathrm{M}^{-1} \mathrm{~cm}^{-1}$ and $42 \mathrm{KDa}$ for HeAlaDH, $51,402 \mathrm{M}^{-1} \mathrm{~cm}^{-1}$ and $42 \mathrm{KDa}$ for $\mathrm{CbFDH}$, $62,840 \mathrm{M}^{-1} \mathrm{~cm}^{-1}$ and $54.4 \mathrm{KDa}$ for HeWT, and $81,735 \mathrm{M}^{-1} \mathrm{~cm}^{-1}$ and $55.2 \mathrm{kDa}$ for CvTA.

\subsection{Enzymatic Assay}

For the soluble enzyme, the activity was measured in the oxidative deamination with $40 \mathrm{mM}$ alanine and $1 \mathrm{mM}$ NAD+ with the appropriate amount of enzyme in $100 \mathrm{mM}$ glycine buffer $\mathrm{pH} 10$ or $\mathrm{pH}$ 8. For the reductive amination, $2.5 \mathrm{mM}$ pyruvate, $250 \mathrm{mM}$ $\mathrm{NH} 4+$, and $0.5 \mathrm{mM}$ of NADH with an appropriate amount of enzyme in $100 \mathrm{mM}$ phosphate buffer $\mathrm{pH} 8$. For $\mathrm{CbFDH}$, the activity assay was performed with $100 \mathrm{mM}$ of ammonium formate and $1 \mathrm{mM}$ NAD+ in phosphate buffer $\mathrm{pH} 8$. The formation or depletion of the cofactor was followed by measuring the absorbance at $340 \mathrm{~nm}\left(\varepsilon=6220 \mathrm{M}^{-1} \mathrm{~cm}^{-1}\right)$ and for HeWT, the activity assay was performed with $2.5 \mathrm{mM}$ pyruvate, $2.5 \mathrm{mM} \mathrm{SMBA}$, and $0.1 \mathrm{mM}$ PLP in phosphate buffer pH8 following the formation of acetophenone at $245 \mathrm{~nm}$ $\left(\varepsilon=12,000 \mathrm{M}^{-1} \mathrm{~cm}^{-1}\right)$.

A unit defined as the $\mu$ mols of either product formed or substrate depleted per minute.

For the immobilised enzyme, between 20 and $50 \mathrm{mg}$ of resin were weighted, and the reaction performed in a total volume of $5 \mathrm{~mL}$ measuring the desired absorbance every two minutes for a total time of $10 \mathrm{~min}$ with the same reaction conditions as stated before. The expressed activity $(\mathrm{U} / \mathrm{g})$ and recovered activity $(\%)$ were calculated as follows:

$$
\text { Expressed activity }(\%)=\frac{\mathrm{UA} / \mathrm{min} x \text { volume of reaction }(\mathrm{mL})}{\varepsilon\left(\mathrm{mM}^{-1} \mathrm{~cm}^{-1}\right) \times \text { Pathlenght }(\mathrm{cm}) \times \mathrm{g} \text { of imm.biocatalyst }}
$$




$$
\text { Recovered activity }(\%)=\frac{\mathrm{U} / \mathrm{mg}(\text { immobilised enzyme })}{\mathrm{U} / \mathrm{mg} \text { of enzyme }(\text { free })} \times 100
$$

\subsection{SDS-PAGE}

SDS-PAGE assay was performed following the original procedure [43]. The running gel (12\%: $1.95 \mathrm{~mL}$ of Tris $\mathrm{HCl} 1.5 \mathrm{M} \mathrm{pH} 8.8,2.25 \mathrm{~mL}$ acrylamide $40 \%, 3.125 \mathrm{~mL}$ of dH2O, $75 \mu \mathrm{L}$ SDS 10\%, $75 \mu \mathrm{L}$ ammonium persulfate $10 \%(w / v)$, and $7.5 \mu \mathrm{L}$ TEMED) was prepared and loaded in between the two glass pieces, adding a few drops of isopropanol on top to avoid the formation of a meniscus. After the gel was polymerised, the stacking gel was prepared and loaded $(0.25 \mathrm{~mL} 1 \mathrm{M}$ Tris $\mathrm{pH} 6.8,0.33 \mathrm{~mL}$ acrylamide $40 \%, 1.4 \mathrm{~mL} \mathrm{dH2O}$, $20 \mu \mathrm{L}$ SDS 10\%, $20 \mu \mathrm{L}$ ammonium persulfate 10\% $(w / v)$, and $3 \mu \mathrm{L}$ TEMED). Before loading, the samples were heated at $90{ }^{\circ} \mathrm{C}$ for at least 5 min after mixed with an equal volume of the $2 \times$ loading buffer $(0.18 \mathrm{M}$ Tris- $\mathrm{HCl}$ buffer $\mathrm{pH} 6,3.8 \mathrm{mM} \beta$-mercaptoethanol, $7.2 \%$ $(w / v)$ SDS, 36\% $(w / v)$ glycerol, and $0.36(w / v)$ bromophenol blue). The assay was run at $30 \mathrm{~mA}, 300 \mathrm{~V}$ for $70 \mathrm{~min}$. The protein marker, unstained protein standard, broad range $(10-200 \mathrm{kDa})$ was loaded as a comparison. The gel was then removed from the mould and either stained with Coomassie blue staining solution (2\% Coomassie brilliant blue R-250 in aqueous solution 50\% methanol and 10\% acetic acid) for 15-30 min following distaining with the distaining solution (aqueous solution $7.5 \%$ methanol and $10 \%$ acetic acid) overnight or with Instant Blue (Expedeon ${ }^{\circledR}$ ) solution overnight.

\subsection{Batch Reactions}

Batch biotransformations with free enzyme were performed with the desired concentration of substrate, $1-2 \mathrm{mg} / \mathrm{mL}$ of enzyme in phosphate buffer $\mathrm{pH} 8$. Samples were withdrawn at different times and the reaction was quenched by adding $450 \mu \mathrm{L}$ of $\mathrm{HCl} 0.2 \%$ and $450 \mu \mathrm{L}$ of acetonitrile. The samples were analysed by HPLC (Dionex UltiMate 3000 (Thermo Fisher, Loughborough, UK), Waters X-Bridge C18 (Waters, Elstree, UK) (3.5 $\mu \mathrm{m}$, $2.1 \times 100 \mathrm{~mm}), 0.8 \mathrm{~mL} / \mathrm{min}$, measuring at 210,250 , and $265 \mathrm{~nm}$ ) to assess the conversion.

\subsection{Immobilisation of HeAlaDH into Epoxy Functionalised Supports}

The support was prepared following previous indicated protocol [27]. For the protein immobilisation, $2 \mathrm{~mL} / \mathrm{g}$ resin with the desired amount of protein in $50 \mathrm{mM}$ phosphate buffer $\mathrm{pH} 8$ were mixed at RT for 4 or $16 \mathrm{~h}$, when no further decrease in the activity could be detected in the supernatant. The immobilisation yield was calculated as the percentage of protein remaining in the supernatant after incubation with respect to the offered protein.

\subsection{Preparation of Dextran-Aldehyde}

To obtain the $50 \%$ oxidised dextran-aldehyde, $10 \mathrm{~g}$ of dextran (35-45 KDa) were dissolved in $100 \mathrm{~mL}$ water and mixed with $1 \mathrm{~g}$ of periodate stirring at room temperature for $2 \mathrm{~h}$. After, it was dialysed against 50 times the volume of distilled water 4 times.

\subsection{Post Immobilisation Coating of Immobilised HeAlaDH}

After the immobilisation, 10 volumes of $5 \mathrm{mg} / \mathrm{mL}$ PEI in $100 \mathrm{mM}$ carbonate buffer $\mathrm{pH} 10$ were mixed with the resin for $1 \mathrm{~h}$ at RT. After that, the resin was filtered and washed thoroughly with water and $50 \mathrm{mM}$ phosphate buffer $\mathrm{pH} 8$ and stored at $4{ }^{\circ} \mathrm{C}$ in the $50 \mathrm{mM}$ phosphate buffer $\mathrm{pH} 8$. For glutaraldehyde, 10 volumes of $5 \mathrm{mg} / \mathrm{mL}$ glutaraldehyde in $50 \mathrm{mM}$ phosphate buffer $\mathrm{pH} 8$ were mixed with the resin for $1 \mathrm{~h}$ at RT. Sequentially, $1 \mathrm{mg} / \mathrm{mL}$ of sodium borohydride was added, and the mix shaken gently for $20 \mathrm{~min}$. After that, the resin was filtered and washed thoroughly with water and $50 \mathrm{mM}$ phosphate buffer pH8 and stored at $4{ }^{\circ} \mathrm{C}$ in the $50 \mathrm{mM}$ phosphate buffer $\mathrm{pH} 8$. The coating method was modified from previously reported protocols. To conclude, for dextran coating, $100 \mathrm{mg}$ of immobilised resin were resuspended in $500 \mu \mathrm{L}$ of $50 \mathrm{mM}$ phosphate buffer $\mathrm{pH} 8$ along with the appropriate amount of dextran poly-aldehyde and left stirring $\mathrm{O} / \mathrm{N}$. After that, $1 \mathrm{mg} / \mathrm{mL}$ of sodium borohydride was added along with $50 \mu \mathrm{L}$ of $900 \mathrm{mM}$ bicarbonate 
buffer $\mathrm{pH} 10$ and the mix was left stirring at $4{ }^{\circ} \mathrm{C}$ for $25 \mathrm{~min}$ before it the biocatalyst was washed thoroughly with water and stored in $50 \mathrm{mM}$ phosphate buffer $\mathrm{pH} 8$.

\subsection{Co-Immobilisation of HeAlaDH and CbFDH}

To the previously activated support, either of $5 \mathrm{mg} / \mathrm{g}$ of resin of CbFDH or $1 \mathrm{mg} / \mathrm{g}$ or resin of HeAlaDH were added and left mixing room temperature. After that, the percentage of immobilised protein was assessed with both the remaining activity and the protein concentration in the supernatant. Then, $1 \mathrm{mg} / \mathrm{g}$ of resin of HeAlaDH or $5 \mathrm{mg} / \mathrm{g}$ of resin of $\mathrm{CbFDH}$ were added and left mixing with the support at room temperature. For $\mathrm{HeAlaDH}$, the mixing time was $4 \mathrm{~h}$ while for $\mathrm{CbFDH}, \mathrm{O} / \mathrm{N}$ incubation was needed to achieve the maximum immobilisation yield. Desorption and blocking were performed as detailed before for HeAlaDH with PEI.

\subsection{Flow Reactions}

Continuous flow biotransformations were performed using a R2 + /R4 flow reactor commercially available from Vapourtec ${ }^{\circledR}$ equipped with an Omnifit ${ }^{\circledR}$ glass column (6.6 $\mathrm{mm}$ i.d. $\times 100 \mathrm{~mm}$ length) filled with an appropriate volume of immobilised enzyme. When needed, two solutions or solvents were mixed using a $\mathrm{T}$ tube before entrance to the column. The flow rate was varied and optimised for each reaction. The exiting flow stream was collected, and the results analysed by HPLC. The samples were analysed by HPLC (Dionex UltiMate 3000, Waters X-Bridge C18 (3.5 $\mu \mathrm{m}, 2.1 \times 100 \mathrm{~mm}), 0.8 \mathrm{~mL} / \mathrm{min}$, measuring at 210, 250, and $265 \mathrm{~nm}$ ) to assess the conversion.

\subsection{Dialysis Assisted Reaction}

A mix of enzymes at the desired concentration were added inside a dialysis membrane with a cut-off (MWCO) of 12 KDa (D9527-100FT from Sigma Aldrich, St. Louis, MO, USA). The membrane secured in both sides and submerged into a glass vial containing 5 times the volume of enzyme cocktail of reaction mixture. The glass vial was left stirring at $37^{\circ} \mathrm{C}$ for at least $24 \mathrm{~h}$. At the desired timepoints, samples were taken from the reaction bulk and analysed by HPLC.

\subsection{HPLC Analysis}

Typically, for compounds with detectable chromophores, samples were appropriately diluted in a solution of $1: 1(v / v) 0.1 \% \mathrm{HCl}$ and $450 \mu \mathrm{L}$ of MeCN to stop the enzymatic reaction. These samples were then analysed by HPLC (Dionex UltiMate 3000, Waters X-Bridge C18 $(3.5 \mu \mathrm{m}, 2.1 \times 100 \mathrm{~mm})$, measuring at 210, 250, and $265 \mathrm{~nm}$ to assess the conversion using a gradient method from 5:95 to $95: 5\left(\mathrm{H}_{2} \mathrm{O}: \mathrm{MeCN}\right.$ 0.1\%TFA) over 4 min with a flow rate of $0.8 \mathrm{~mL} / \mathrm{min}$.

For compounds with an amine functionality with no detectable fluorophore, FMOC derivatisation was used to enable their detection. Typically, $100 \mu \mathrm{L}$ of a maximum of $10 \mathrm{mM}$ of the desired compound were mixed with $200 \mu \mathrm{L}$ of $100 \mathrm{mM}$ borate buffer $\mathrm{pH} 9$. To the mix, $400 \mu \mathrm{L}$ of $15 \mathrm{mM}$ FMOC diluted in MeCN were added. The sample was properly mixed and left for at least $10 \mathrm{~min}$ before mixing $200 \mu \mathrm{L}$ of it with $400 \mu \mathrm{L}$ of MeCN and $400 \mu \mathrm{L}$ of $0.1 \% \mathrm{HCl}$. Samples were run using a gradient method from 40:60 to 95:5 $\left(\mathrm{H}_{2} \mathrm{O}: \mathrm{MeCN}\right.$ 0.1\% TFA) over 4 min with a flow rate of $0.8 \mathrm{~mL} / \mathrm{min}$.

The retention times for the different chemicals were: $3.09 \mathrm{~min}$ for vanillin, $4.14 \mathrm{~min}$ for cinnamaldehyde, $3.12 \mathrm{~min}$ for cinnamyl amine, 1.58mins for alanine-FMOC, and $4.13 \mathrm{~min}$ for cyclohexylamine-FMOC.

Supplementary Materials: The following are available online at https:/ /www.mdpi.com/article/10 .3390/catal11040520/s1. Figure S1. SDS-page analysis of HeAlaDH expression, Figure S2. Kinetic characterisation of $\mathrm{HeAlaDH}$ in both the oxidative deamination and the reductive amination direction, Figure S3. Cosolvent effect on the stability of HeAlaDH, Figure S4. pH effect on the stability of HeAlaDH, Figure S5. Amination of vanillin at the $10 \mathrm{mM}$ scale with different equivalents of alanine and the presence (+) or absence (-) of the cascade for the amino donor recycling, Figure S6. Amination 
of vanillin at the 10- and 50-mM scale with 1 equivalent of alanine, Figure S7. A. SDS-PAGE analysis of the immobilised biocatalysts, Figure S8. Stability of the different biocatalysts in the presence of the different additives, Table S1: Results of the immobilisation of HeAlaDH in various supports, Table S3: Co-immobilization of HeAlaDH ( $1 \mathrm{mg} / \mathrm{g})$ and $\mathrm{CbFDH}(5 \mathrm{mg} / \mathrm{g})$ in the three different tested resins, Table S4. Recovered activities and specific activity of the biocatalysts of the three different enzymes.

Author Contributions: Conceptualisation, F.P.; methodology, F.P. and D.R.P.; experimental Z.N. and D.R.P.; writing —original draft preparation, D.R.P.; writing—review and editing, F.P.; All authors have read and agreed to the published version of the manuscript.

Funding: The authors wish to acknowledge the Biotechnology and Biological Research Council [grant number BB/P002536/1] and H2020 ERACoBioTech programme (project ID: 61 HOMBIOCAT) also funded through the Biotechnology and Biological Sciences Research Council [grant number $\mathrm{BB} / \mathrm{R} 021287 / 1]$.

Data Availability Statement: The data that support the findings of this study are available from the corresponding author, F.P., upon reasonable request.

Conflicts of Interest: The authors declare no conflict of interest.

\section{References}

1. Gröger, H. Biocatalytic concepts for synthesizing amine bulk chemicals: Recent approaches towards linear and cyclic aliphatic primary amines and $\omega$-substituted derivatives thereof. Appl. Microbiol. Biotechnol. 2019, 103, 83-95. [CrossRef]

2. Pelckmans, M.; Renders, T.; Van De Vyver, S.; Sels, B.F. Bio-based amines through sustainable heterogeneous catalysis. Green Chem. 2017, 19, 5303-5331. [CrossRef]

3. Kelly, S.A.; Pohle, S.; Wharry, S.; Mix, S.; Allen, C.C.R.; Moody, T.S.; Gilmore, B.F. Application of $\omega$-Transaminases in the Pharmaceutical Industry. Chem. Rev. 2018, 118, 349-367. [CrossRef] [PubMed]

4. Galman, J.L.; Slabu, I.; Weise, N.J.; Iglesias, C.; Parmeggiani, F.; Lloyd, R.C.; Turner, N.J. Biocatalytic transamination with near-stoichiometric inexpensive amine donors mediated by bifunctional mono- and di-amine transaminases. Green Chem. 2017, 19, 361-366. [CrossRef]

5. Cassimjee, K.E.; Manta, B.; Himo, F. A quantum chemical study of the $\omega$-transaminase reaction mechanism. Org. Biomol. Chem. 2015, 13, 8453-8464. [CrossRef]

6. Savile, C.K.; Janey, J.M.; Mundorff, E.C.; Moore, J.C.; Tam, S.; Jarvis, W.R.; Colbeck, J.C.; Krebber, A.; Fleitz, F.J.; Brands, J.; et al. Biocatalytic Asymmetric Synthesis of Chiral Amines from Ketones Applied to Sitagliptin Manufacture. Science 2010, 329, 305-309. [CrossRef] [PubMed]

7. Martin, A.R.; Shonnard, D.; Pannuri, S.; Kamat, S. Characterization of free and immobilized (S)-aminotransferase for acetophenone production. Appl. Microbiol. Biotechnol. 2007, 76, 843-851. [CrossRef]

8. Guo, F.; Berglund, P. Transaminase biocatalysis: Optimization and application. Green Chem. 2017, 19, 333-360. [CrossRef]

9. Börner, T.; Rämisch, S.; Bartsch, S.; Vogel, A.; Adlercreutz, P.; Grey, C. Three in One: Temperature, Solvent and Catalytic Stability by Engineering the Cofactor-Binding Element of Amine Transaminase. ChemBioChem 2017, 18, 1482-1486. [CrossRef] [PubMed]

10. Roura Padrosa, D.; Alaux, R.; Smith, P.; Dreveny, I.; López-Gallego, F.; Paradisi, F. Enhancing PLP-Binding Capacity of Class-III $\omega$-Transaminase by Single Residue Substitution. Front. Bioeng. Biotechnol. 2019, 7, 282. [CrossRef]

11. Börner, T.; Rämisch, S.; Reddem, E.R.; Bartsch, S.; Vogel, A.; Thunnissen, A.M.W.H.; Adlercreutz, P.; Grey, C. Explaining Operational Instability of Amine Transaminases: Substrate-Induced Inactivation Mechanism and Influence of Quaternary Structure on Enzyme-Cofactor Intermediate Stability. ACS Catal. 2017, 7, 1259-1269. [CrossRef]

12. Kelefiotis-Stratidakis, P.; Tyrikos-Ergas, T.; Pavlidis, I.V. The challenge of using isopropylamine as an amine donor in transaminase catalysed reactions. Org. Biomol. Chem. 2019, 17, 1634-1642. [CrossRef]

13. Huisman, G.W.; Collier, S.J. On the development of new biocatalytic processes for practical pharmaceutical synthesis. Curr. Opin. Chem. Biol. 2013, 17, 284-292. [CrossRef]

14. Leipold, L.; Dobrijevic, D.; Jeffries, J.W.E.; Bawn, M.; Moody, T.S.; Ward, J.M.; Hailes, H.C. The identification and use of robust transaminases from a domestic drain metagenome. Green Chem. 2019, 21, 75-86. [CrossRef]

15. Green, A.P.; Turner, N.J.; Reilly, E.O. Chiral Amine Synthesis Using w -Transaminases: An Amine Donor that Displaces Equilibria and Enables High-Throughput Screening. Angewandte 2014, 10714-10717. [CrossRef] [PubMed]

16. Baud, D.; Ladkau, N.; Moody, T.S.; Ward, J.M.; Hailes, H.C. A rapid, sensitive colorimetric assay for the high-throughput screening of transaminases in liquid or solid-phase. Chem. Commun. 2015, 51, 17225-17228. [CrossRef] [PubMed]

17. Slabu, I.; Galman, J.L.; Weise, N.J.; Lloyd, R.C.; Turner, N.J. Putrescine Transaminases for the Synthesis of Saturated Nitrogen Heterocycles from Polyamines. Chem CatChem 2016, 8, 1038-1042. [CrossRef]

18. Martínez-Montero, L.; Gotor, V.; Gotor-Fernández, V.; Lavandera, I. Stereoselective amination of racemic sec-alcohols through sequential application of laccases and transaminases. Green Chem. 2017, 19, 474-480. [CrossRef]

19. Koszelewski, D.; Lavandera, I.; Clay, D.; Guebitz, G.M.; Rozzell, D.; Kroutil, W. Formal asymmetric biocatalytic reductive amination. Angew. Chem. Int. Ed. 2008, 47, 9337-9340. [CrossRef] [PubMed] 
20. Richter, N.; Farnberger, J.E.; Pressnitz, D.; Lechner, H.; Zepeck, F.; Kroutil, W. A system for $\omega$-transaminase mediated (R)amination using L-alanine as an amine donor. Green Chem. 2015, 17, 2952-2958. [CrossRef]

21. Klatte, S.; Wendisch, V.F. Role of L-alanine for redox self-sufficient amination of alcohols. Microb. Cell Fact. 2015, 14, 1-10. [CrossRef]

22. Koszelewski, D.; Lavandera, I.; Clay, D.; Rozzell, D.; Kroutil, W. Asymmetric synthesis of optically pure pharmacologically relevant amines employing $\omega$-transaminases. Adv. Synth. Catal. 2008, 350, 2761-2766. [CrossRef]

23. Contente, M.L.; Dall'Oglio, F.; Tamborini, L.; Molinari, F.; Paradisi, F. Highly Efficient Oxidation of Amines to Aldehydes with Flow-based Biocatalysis. ChemCatChem 2017, 9, 3843-3848. [CrossRef]

24. Abaházi, E.; Sátorhelyi, P.; Erdélyi, B.; Vértessy, B.G.; Land, H.; Paizs, C.; Berglund, P.; Poppe, L. Covalently immobilized Trp60Cys mutant of $\Omega$-transaminase from Chromobacterium violaceum for kinetic resolution of racemic amines in batch and continuous-flow modes. Biochem. Eng. J. 2018, 132, 270-278. [CrossRef]

25. Planchestainer, M.; Contente, M.L.; Cassidy, J.; Molinari, F.; Tamborini, L.; Paradisi, F. Continuous flow biocatalysis: Production and in-line purification of amines by immobilised transaminase from Halomonas elongata. Green Chem. 2017, 19, 372-375. [CrossRef]

26. Truppo, M.D.; Strotman, H.; Hughes, G. Development of an Immobilized Transaminase Capable of Operating in Organic Solvent. Chem CatChem 2012, 4, 1071-1074. [CrossRef]

27. Agustian, J.; Kamaruddin, A.H.; Bhatia, S. Enzymatic membrane reactors: The determining factors in two separate phase operations. J. Chem. Technol. Biotechnol. 2011, 86, 1032-1048. [CrossRef]

28. Possebom, G.; Nyari, N.L.D.; Zeni, J.; Steffens, J.; Rigo, E.; di Luccio, M. Esterification of fatty acids by Penicillium crustosum lipase in a membrane reactor. J. Sci. Food Agric. 2014, 94, 2905-2911. [CrossRef] [PubMed]

29. Kaulmann, U.; Smithies, K.; Smith, M.E.B.; Hailes, H.C.; Ward, J.M. Substrate spectrum of $\omega$-transaminase from Chromobacterium violaceum DSM30191 and its potential for biocatalysis. Enzym. Microb. Technol. 2007, 41, 628-637. [CrossRef]

30. Cerioli, L.; Planchestainer, M.; Cassidy, J.; Tessaro, D.; Paradisi, F. Characterization of a novel amine transaminase from Halomonas elongata. J. Mol. Catal. B Enzym. 2015, 120, 141-150. [CrossRef]

31. Schütte, H.; Flossdorf, J.; Sahm, H.; Kula, M.-R. Purification and Properties of Formaldehyde Dehydrogenase and Formate Dehydrogenase from Candida boidinii. Eur. J. Biochem. 1976, 62, 151-160. [CrossRef] [PubMed]

32. Benítez-Mateos, A.I.; Contente, M.L.; Velasco-Lozano, S.; Paradisi, F.; López-Gallego, F. Self-Sufficient Flow-Biocatalysis by Coimmobilization of Pyridoxal 5'-Phosphate and w-Transaminases onto Porous Carriers. ACS Sustain. Chem. Eng. 2018, 6, 13151-13159. [CrossRef]

33. Bolivar, J.M.; Wilson, L.; Ferrarotti, S.A.; Fernandez-Lafuente, R.; Guisan, J.M.; Mateo, C. Evaluation of different immobilization strategies to prepare an industrial biocatalyst of formate dehydrogenase from Candida boidinii. Enzym. Microb. Technol. 2007, 40, 540-546. [CrossRef]

34. Mateo, C.; Grazú, V.; Pessela, B.C.C.; Montes, T.; Palomo, J.M.; Torres, R.; López-Gallego, F.; Fernández-Lafuente, R.; Guisán, J.M. Advances in the design of new epoxy supports for enzyme immobilization-stabilization. Biochem. Soc. Trans. 2008, 35, 1593-1601. [CrossRef] [PubMed]

35. Bolivar, J.M.; Rocha-Martín, J.; Mateo, C.; Guisan, J.M. Stabilization of a highly active but unstable alcohol dehydrogenase from yeast using immobilization and post-immobilization techniques. Process Biochem. 2012, 47, 679-686. [CrossRef]

36. Lopez-Gallego, F.; Betancor, L.; Hidalgo, A.; Dellamora-Ortiz, G.; Mateo, C.; Fernández-Lafuente, R.; Guisán, J.M. Stabilization of different alcohol oxidases via immobilization and post immobilization techniques. Enzym. Microb. Technol. 2007, 40, $278-284$. [CrossRef]

37. Trobo-Maseda, L.; Orrego, A.H.; Moreno-Pérez, S.; Fernández-Lorente, G.; Guisan, J.M.; Rocha-Martin, J. Stabilization of multimeric sucrose synthase from Acidithiobacillus caldus via immobilization and post-immobilization techniques for synthesis of UDP-glucose. Appl. Microbiol. Biotechnol. 2018, 102, 773-787. [CrossRef]

38. Arana-Peña, S.; Carballares, D.; Morellon-Sterlling, R.; Berenguer-Murcia, Á.; Alcántara, A.R.; Rodrigues, R.C.; FernandezLafuente, R. Enzyme co-immobilization: Always the biocatalyst designers' choice ... or not? Biotechnol. Adv. 2020, 107584. [CrossRef]

39. Zhang, J.; Li, F.; Wang, R.; Tan, X.; Hagedoorn, P.-L. Dialysis membrane enclosed laccase catalysis combines a controlled conversion rate and recyclability without enzyme immobilization. AMB Express 2020, 10, 19. [CrossRef]

40. Bommarius, A.S.; Paye, M.F. Stabilizing biocatalysts. Chem. Soc. Rev. 2013, 42, 6534. [CrossRef]

41. Andersson, M.M.; Hatti-Kaul, R. Protein stabilising effect of polyethyleneimine. J. Biotechnol. 1999, 72, 21-31. [CrossRef]

42. Simpson, R.J. Stabilization of proteins for storage. Cold Spring Harb. Protoc. 2010, 5, pdb.top79. [CrossRef] [PubMed]

43. Laemmli, U.K. Cleavage of structural proteins during the assembly of the head of bacteriophage T4. Nature 1970, 227, 680-685. [CrossRef] [PubMed] 